\title{
アスファルトコンクリート発生材を用いた 道路路床の構築法に関する実験的研究
}

\author{
山田幹雄 ${ }^{1} \cdot$ 松島保志 $^{2} \cdot$ 佐野博昭 $^{3} \cdot$ 奥村充司 $^{4}$ \\ ${ }^{1}$ 正会員 工博 福井工業高等専門学校教授 福境都市工学科（T916-8507県鲭江市下司町）

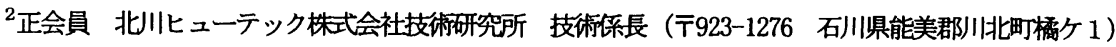 \\ ${ }^{3}$ 正会員 博(工) 石川工業高等専門学校助教授 環境都市工学科（广929-0392 石川県河北郡津蟠町北中条) \\ ${ }^{4}$ 正会員 工修 福井工業高等専門学校满師 環境都市工学科（T916-8507 福井県鲭江市下司町）
}

\begin{abstract}
本研究では建設副産物の有效利用の一環として，また，補修周期の延伸化の一策として，再生混合所に搬入したアスフ アルトコンクリート発生材の一次選别時に生じるグリズリフィーダ通過材を活用した路床構築の可能性について検討した. 模擬路床の構築試験に先立ち，室内で粒径を揃えた材料を安定材とともに訌料土に加えて CBR や一軸圧縮強さの推移を 調べたところ，混入量を多くするほど安定処理効果は大きくなることが確かめられた.ささらに，構築試験および事後試験


の固化の進行には路床温度が関与すること，耐水性を通常の安定処理土と比較してもとくに遜色のないことが示された.
\end{abstract}

Key Words: reclaimed asphalt mixture, improvement of subgrade soil, California bearing ratio, unconfined compressive strength, coefficient of subgrade reaction

\section{1. まえがき}

新たな道路整備 5 ヶ年計画（第12次）のもと，高規格 幹線道路から生活道路までの多岐にわたる通路の新設, 改筑および補修工事が円滑に推進されつつある. 道路整 備事業に関して, 過去40年間の舗装の「新設・改築」と 「維持・修繕」とに要した費用を集計した資料によれば, 1990年以降は後者が前者を上回っており，その傾向は今 後も継続する見通しにあるとされている ${ }^{1)}$. したがって, これまでにも増してライフサイクルコストを念頭に置い た舗装技術の開発が重要視されることになる.

補修周期の延伸化，すなわち，舗装の長寿命化を達成 する上には(1)構成材料をも含めた断面構造の見直しと設 計法の確立，(2)舗装と一体となって交通荷重を分散する 路床の支持力向上（路床の構築）が不可欠な要因となる.

長寿命化舗装への取り組み例として, 日本道路公団に おいてはコンポジット舗装を，東京都では長期供用舗装 （L S P）を中心に経済効果，断面構造や施工法に関す る検討が行われている. しかし, これらの舗装は重交通 路線を対象とするものであり, 設計交通量の区分が $\mathrm{L}$, A交通に該当する路線およひ国内の大部分を占める簡易 舖装区間などの軽交通道路については，別の視点から供 用性の長期持続策を検討する必要がある ${ }^{2)}$.
ライフサイクルコストを考虑に入れた舗装設計の端緒 は1992年に改訂されたアスファルト舗装要綱3)にあるが, そこには上記(1)構成材料に関して, 新たに地域産材料 や副産物が舗装用資材に組み入れられた。このうちの副 産物の舗装への活用について, 著者らの一部はかつて「再 生資源の利用の促進に関する法律（リサイクル法）」で 指定副産物 ${ }^{4)}$ に位置付けられている石炭灰を取り上げ, これを主材とする下層路盤および単一層路盤を設計交通 量 L, A 交通の路線に築造して, 交通開放後の路面性状 や舗装強度の経時変化などを調查したことがある ${ }^{5), 6)}$.

これらの研究において，石炭灰を天然骨材の代替に用 いて築造した路盤であっても施工後短期間のうちに舗装 に構造的破損を生じる恐れはなく，かつ，品質規格や等 值換算係数は既存の石灰安定処理材料の諸值を準用でき ることが確認された. ただし，文献 5)，6）ともに研究 目的を固化した石炭灰路盤の耐久性の評価に置いていた ので，訊験施工は設計 $C B R \geqq 12 \%$ 堅固な路床上で行っ た.このため, 軟弱路床の上に築造した場合の舗装の举 動まで検証することはできなかったが，それでも，計 7 箇所での実地検分を通して路床の構築にも副産物を有効 利用できる余地と可能性のあることを経験的に認識した.

そこで，著者らは改めて上記(2)にかかわる方策を，リ サイクル法において同じく指定副産物扱いとされている 
アスファルトコンクリート発生材（リサイクル法ではア スファルト・コンクリート塊と呼称) を活用して講じる ことができるかどうかについて検討することにした.

アスファルトコンクリート発生材は既設舗装の補修工 事などに際して生じるものであり, 通常は現場からアス ファルト混合所に併設されている再資源化施設へ搬入さ れ, 解砕・分級工程を経て再生加熱アスファルト混合物 用骨材およひ再生路盤材として製品化される7).

文献 8）によれば, アスファルトコンクリート発生材 の現場排出量は1990年度に約1800万トン, 1993年度に約 2200万トン，1995年度には約3600万トンとなっており， 道路整備の進捗にともない増加の一途を辿っている. こ れに対して, 再利用率は1990年度から1993年度の 3 年間 で50\%から78\%へと急上昇したものの，1995年度の実績 は81\%に止まり，幾分鈍化の兆しが現れている。

この点について, 文献 9）には再資源化施設運営上の 問題として, 需給の時期的な不均衡により年度途中に累 積ストック量が急増し，ストックヤードの調整に支障を きたすこと，そして，これには施設拡張にあたっての用 地の確保難が介在することが述べられている. なお，地 域にもよるが, 需給の不均衡は再生加熱アスファルト混 合物用骨材に比べて, 主たる用途を下層路盤や各種構造 物の裹込めとする再生路盤材に多くみられるようである.

以上のことから，著者らは用途ならびに消費量の㹡大 を図るための一策として, 再生路盤材を用いた路床の構 築を試行してみることにした. ここで，再生路盤材は製 造プラントの仕様により, 搬入したアスファルトコンク リート発生材の一次選別時に生じる粒径 40〜 $0 \mathrm{~mm}$ のグリ ズリフィーダ通過材とアスファルトコンクリート, セメ ントコンクリート, 路盤の各発生材を一定の割合で混合 したものとに大別される(10). このうち, 今回の研究に試 用したのは前者の方であり, 後者との混同を避けるため にこれ以後は単に「発生材」と記すことにする.

本論文では，発生材を安定材とともに混ぜ合わせた試 料土の支持力, 強度および変形特性を室内 $C B R$ 試験,

一軸圧縮試験にもとづいて調べた結果を第 3 章に, 次い で, 屋外に構築した模擬路床（ただし，舗装は設けず） で実施した平板載荷試験の結果ならびに事後試験として 改良路床土の温度依存性や水に対する抵抗性を室内で確 認した結果を第 4 章に述べる. 最後に, 発生材混入の有 無と $C B R$ の増分との関係について試算した結果を第 5 章に記述する ${ }^{(1) \sim 13)}$.

\section{2. 材料の性質およひ配合条件}

上述したように，本研究の主眼はグリズリフィーダ通 過材の路床構築材料としての有用性を探究することにあ るが, 室内試験に着手するにあたって当初から粒径40〜

\section{表-1 発生材の品質}

\begin{tabular}{|c|c|c|}
\hline 発 生 材 & 粒径4 0～0 m & 粒径 $13 \sim 10 \mathrm{~mm}$ \\
\hline 表 乾 比重 & $2.18 \sim 2.44$ & $2.16 \sim 2.43$ \\
\hline 見掛け比重 & $2.44 \sim 2.57$ & $2.44 \sim 2.56$ \\
\hline 吸 水 率 (\%) & $2.6 \sim 4.6$ & $2.6 \sim 4.7$ \\
\hline すりへり減量 (\%) & 約 20 & 約 20 \\
\hline
\end{tabular}

\section{表ー2 試料土の物理的性質および化学成分組成}

\begin{tabular}{|c|c|c|}
\hline 採 & 石川県加賀市 & 石川県金沢市 \\
\hline 料 & 箱宮土 & 二俣 土 \\
\hline 土粒子の密度 $\left(\mathrm{g} / \mathrm{cm}^{3}\right)$ & 2.71 & 2.60 \\
\hline 最 適 含 水 比 （\%) & 20.8 & 29.1 \\
\hline 最大乾燥密度 $\left(\mathrm{g} / \mathrm{cm}^{3}\right)$ & 1.67 & 1.39 \\
\hline (\%) & 60.8 & 62.4 \\
\hline シルト 分 & 13.2 & 29.4 \\
\hline 粘 土 分 & 26.0 & 8.2 \\
\hline 均 等 係 数 & - & 21.61 \\
\hline 曲 率 係 数 & - & 3.13 \\
\hline 液 性 限 界 & 43.2 & 42.0 \\
\hline 塑 性 限 界 & 22.9 & 27.8 \\
\hline 塑 性 指 数 & 20.3 & 14.2 \\
\hline 日本統一土啠 & $\begin{array}{c}\text { 粘質土 } \\
\text { [C L ] }\end{array}$ & $\begin{array}{c}\text { シル ル } \\
\text { (低液性限界) } \\
\text { [ML] }\end{array}$ \\
\hline 二酸化ケイ素 & 67.7 & 68.1 \\
\hline 酸化アルミニウム & 16.0 & 15.4 \\
\hline 酸 化 第 二 鉄 & 6.9 & 3.0 \\
\hline 酸化カルシウム & 0.6 & 1.3 \\
\hline 酸化マグネシウム & 0.1 & 0.5 \\
\hline 酸化カリウム & 0.87 & 3.14 \\
\hline 酸化ナトリウム & 0.15 & 2.34 \\
\hline 強 熱 减 量 & 7.0 & 5.0 \\
\hline 水素イオン灙度指数 $[\mathrm{p} \mathrm{H}]$ & 5.54 & 6.84 \\
\hline
\end{tabular}

Ommの発生材を用いるのではなく，このような材料を混 ぜ合わせた土の基本的な性質を把握するために粒度範囲 を狭めた状態から，すなわち，ふるい分けを行ってほぼ 単粒度とした発生材（粒径13〜10 m) から先に取り扱う ことにした. 表一 1 に, 使用した発生材の品質を示す.

試料土としては, 石川県加賀市箱宮地区の土取り場よ り入手した土（以後，箱宮土と称する）および金沢市二 俣地区の道路拡幅工事現場で採取した土（以後，二俣土 と称する）を使用した．室内試験には，空気乾燥した試

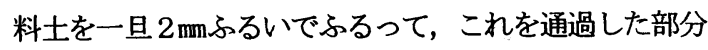
のみを用いた．箱宮土，二俣土の物理的性質および化学 成分組成を表一 2 に示す.

室内試験では, 初めに, 試料土の含水比と $C B R$ との 関係を調べた. $C B R$ 試験は, JIS A 1211に示されてい る方法(14) に淮拠して実施した. 試験結果を図一1に示す. アスファルト舗装要網には設計 $C B R<3 \%$ の路床は支持 


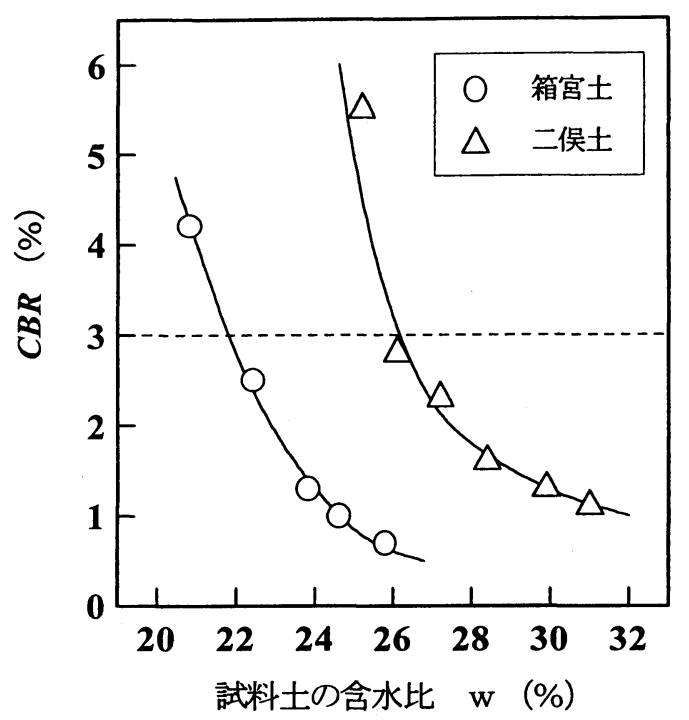

図-1 試料土の含水比と $C B R$ との関係

力の改善を要するとされており，これに倣えば箱宮土は

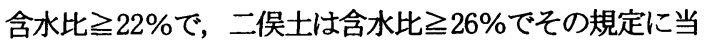
て嵌まることになる.このことから，箱宮土は含水比を 予め $22 \%$ \%たは $25 \%$ 二俣土については $26 \%$ \%たは $28 \%$ に調整した上で, 以降の $C B R$ 試験および一軸圧縮 試験に供することにした.

次に, 試料土に単粒度とした発生材のみを混入したと きのCBR（JIS A 1211準好）を求めた.この試験におけ る箱宮土の含水比は $22 \%$ ，二俣土は $26 \%$ とし，発生材の 混入率は試料土の乾燥質量の $10 \sim 40 \%$ とし. 図一2は, 試験結果をまとめたものである.この図より, 発生材の 混入率を高くするにしたがって $C B R$ は大きくなるもの の, 発生材量を 4 倍としても $C B R$ の増加は $2 \%$ 末満に 止まることがわかる.これより, 発生材の混入率は $10 \%$, $20 \%$ の 2 種類として, 以降の室内および屋外試験を実施 することにした.

一般に，土質安定処理において砂質土にはセメントが， 粘性土には石灰が効果的とされているが，これらに加え てここ20年ほどの間にセメント系, 石灰系の固化材の使 用もかなり増えてきている，そこで，今回採用した試料 土により適する安定材を選定するために，取り敢えず, 箱宮土には普通ポルトランドセメント, セメント系固化 材 (一般軟弱土用) および工業用消石灰（1 号）を添加 したときの $C B R$ を, また, 二俣土には普通ポルトラン ドセメントとセメント系固化材とを添加したときの $C B R$ を「安定処理土の $C B R$ 試験方法」 ${ }^{15)} に$ 淮じて求 めた. 以後, 本論文ではこれらの安定材をセメント, 固 化材, 消石灰と略称する.

試験結果を表一ろに示す。ここに，安定材の添加率は

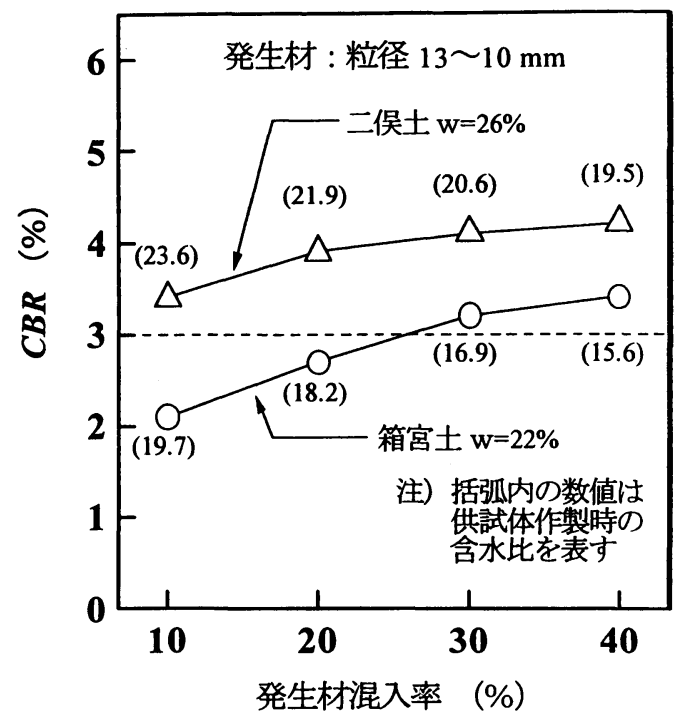

图-2 発生材混入率と $C B R$ との関係

表一3 安定処理土の $C B R$ 試験結果 (発生材無混入)

\begin{tabular}{|c|c|c|c|c|c|}
\hline \multirow{2}{*}{ 安定材 } & \multirow{2}{*}{$\begin{array}{c}\text { 添加率 } \\
(\%)\end{array}$} & \multicolumn{2}{|c|}{ 箱宮土 } & \multicolumn{2}{|c|}{ 二俣士 } \\
\hline & & $\mathrm{w}=22 \%$ & $w=25 \%$ & $w=26 \%$ & $w=28 \%$ \\
\hline \multirow{3}{*}{$\begin{array}{l}\text { 普通ポルト } \\
\text { ランドセメ } \\
\text { ント }\end{array}$} & 2 & 8.4 & 6.4 & 15.5 & 8.1 \\
\hline & 4 & 70.8 & 53.4 & 86.7 & 74.8 \\
\hline & 6 & 152.2 & 100.8 & 170.8 & 129.6 \\
\hline \multirow{3}{*}{$\begin{array}{l}\text { セメント系 } \\
\text { 固化材 }\end{array}$} & 2 & 12.4 & 5.9 & 10.3 & 5.6 \\
\hline & 4 & 74.5 & 49.4 & 102.2 & 81.2 \\
\hline & 6 & 145.9 & 112.2 & 196.6 & 146.0 \\
\hline \multirow{3}{*}{$\begin{array}{l}\text { 工業用 } \\
\text { 消石灰 }\end{array}$} & 2 & 18.8 & 12.6 & - & - \\
\hline & 4 & 194.2 & 104.2 & - & - \\
\hline & 6 & 268.3 & 175.4 & - & - \\
\hline
\end{tabular}

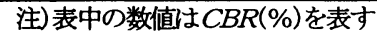

試料土の乾燥質量に対する值である. この表から, 著者 らは箱宮土，二俣土にセメントおよひ固化材を添加した 場合の安定処理効果は, 箱宮土については双方でほぼ同 等, 二俣土については後者の方がいくらか有利とみなし て，引き続き実施する $C B R$ 試験や一軸圧縮試験におい て箱宮土にはセメントを, 二俣土には固化材を加えるこ とにした. なお，箱宮土に消石灰を $4 \%$ 以上添加して作 製した供試体の $C B R$ は通常の改良目標值である20\%を はるかに超えて大きくなったことから，セメント安定処 理のシリーズと固化性状を比較する必要が生じたときに 限っての使用に止めた。

以上の予備的な試験から得られた結果を踏まえて, 単 粒度の発生材を用いて作製する供試体の配合条件を表一 4のように定めた. ここで, シリーズBおよびCにおけ る発生材の混入率は試料土の乾燥質量に対する值であり, また, 安定材の添加率は試料土と発生材との合計乾燥質 
表一4 材料の配合条件（単粒度の発生材を用いる室内試験）

\begin{tabular}{|c|c|}
\hline シリーズ & 安定材添加率および発生材混入率 \\
\hline $\bar{A}$ & 試料土 ${ }^{1)}+$ 安定材 $2,4,6 \%^{2)}$ \\
\hline B & 試料土 + 安定材 $2,4,6 \%+$ 発生材 $10 \%^{3)}$ \\
\hline $\mathrm{C}$ & 試料土 + 安定材 $2,4,6 \%+$ 発生材 $20 \%$ \\
\hline
\end{tabular}

1）設定含水比は箱宮土 22 または $25 \%$ ，二俣土 26 または $28 \%$

2）箱宮土には普通ポルトランドセメントおよひ業用消石灰を使用 二俣土にはセメント系固化材を使用

3) 粒径 13 10 $\mathrm{mm}$

量に対する值である.

3. 単粒度の発生材を混入した安定処理土の支持 力, 強度および変形特性

図一3は，各シリーズの供試体で求めた $C B R$ を比較 したものである. 箱宮土, 二俣土ともに $C B R$ はシリー ズA，B，Cの順に，すなわち, 試料土に発生材を混入 する方が，そして，その量を多くする方が大きくなって いることがわかる.

今回の試験では，養生期間中の $C B R$ の変化を調べる 目的で 1 つ配合条件につき同時に 3 本の供試体を作製 し，これらの作製直後，空気中養生終了時および水浸養 生終了時における $C B R$ を求めた。

試験結果の 1 例を図一 4 に示す.この図は，含水比を $22 \%$ に調整した箱宮土にセメントを $4 \%$ 添加したシリー ズA， B，Cの結果をまとめたものであるが，水浸養生 中も $C B R$ は大きくなっており, 空気中養生終了時から の増分は通常の安定処理土であるシリーズAで約 $20 \%$, これに発生材を加えたシリーズB，Cでは約 $50 \%$ に達し ていることがわかる.このような傾向は【箱宮土十セメ ント]および [二俣土+固化材] をべースとするすべて の供試体で認められ，安定材の添加率を高くするほど水 浸養生中におけるCBRの増分は大きくなった. ただし， 試料土の設定含水比との関係および発生材の混入率との 関係については明らかでなかった. なお，【箱宮土+消 石灰了をべースとする供試体からは，水浸養生終了時の $C B R$ は空気中養生時の $C B R$ にほぼ等しい，もしくは， 1 割程度低下寸るという結果が得られた。

4 日間の水浸養生中に生じた吸水脰張量について，当 初は発生材を加えることで反ってその量が大きくなるこ とを奬念していたが，実際には試料土と安定材との組み 合わせおよび発生材の多少の区別なく，吸水膨張量はい ずれも0. $1 \mathrm{~mm}$ 末満であった.

ここまでに示した $C B R$ 試験において, 粒径の揃った 発生材を単体で試料土に混入しても $C B R$ の増加はほと んど期待できないものの，これを安定材とともに混ぜ合 わせた場合には路床支持力は相乗的に改善され，かつ，



図－3 配合条件による $C B R$ 比較

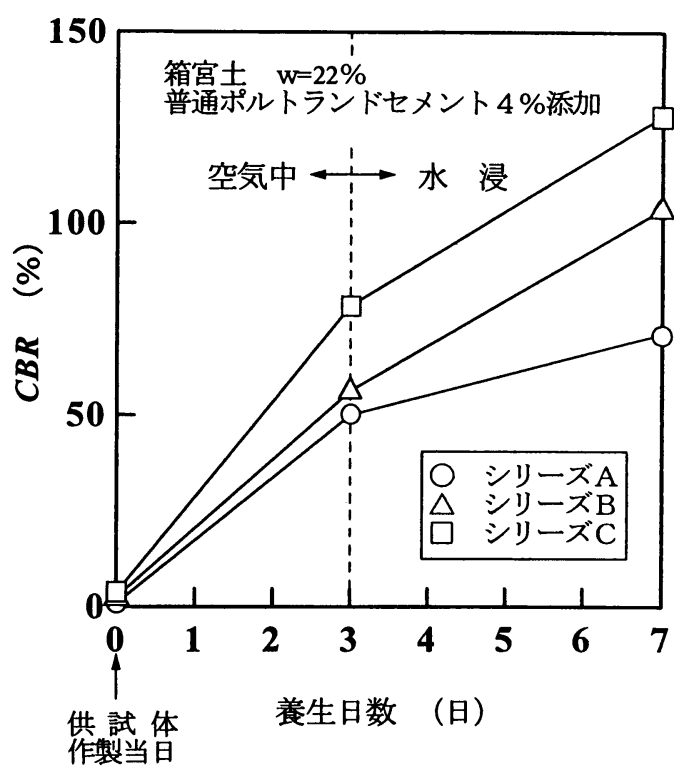

図-4 養生期間中における $C B R$ 推移（箱宮土の例）

吸水により大きな体積膨張を生じる恐れは少ないことが 確かめられた.

そこで, 次の段階として，このような相乗的な効果が 支持力面のみならず強度面にも現れるかどうかを調べる ために, $C B R$ 試験に用いた供試体の初期の含水比と乾 燥密度とを目標に作製した供試体に対する一軸圧縮試験 に移行した.

一軸圧縮試験に用いた供試体の寸法は直径約 $100 \mathrm{~mm}$ ，高 さ約 $127 \mathrm{~mm}$ であり，作製にあたってはそれぞれの配合条 件に応じて混合した材料を二つ割りモールドの中に入れ これを $20 \mathrm{~mm} / \mathrm{min} の$ 速度で静的に締固めた。作製した供試 
箱宮土 $\mathrm{w}=22 \%$, 普通ポルトランドセメント $4 \%$ 添加 OシリーズA $\triangle$ ヘシリーズB ロシリーズC

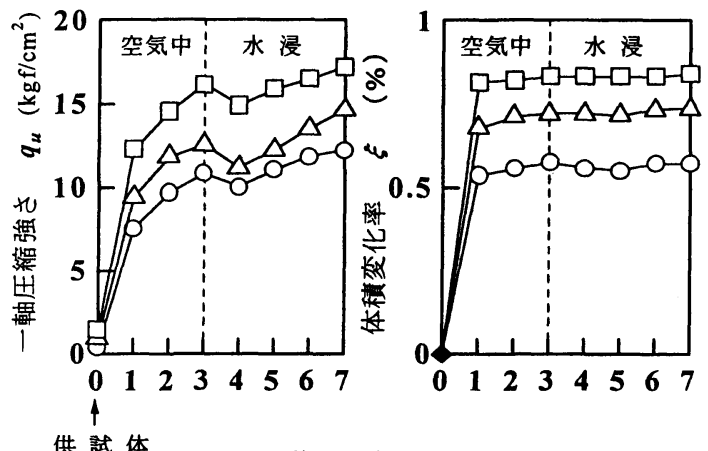

供試体

養生日数 （日）

図一5 養生期間中にお゙ける一軸圧縮強さおよび 体積変化率の推移（箱宮土の例）

体は直ちにビニール袋に入れて厳封し， $C B R$ 試験に準 じて温度 $20^{\circ} \mathrm{C}$ の恒温室内でセメントおよび固化材を添加 して作製した供試体は 3 日間, 消石灰を添加した供試体 は6 日間の空気中養生を行い，その後，供試体をビニ一 ル袋から取り出して同じ恒温室の水槽の中に 4 日間静置 した. 養生終了時には供試体の直径, 高さを数箇所で測 定し，作製時の寸法と比較した。一軸圧縮試験は，1\% /minのひずみ速度で実施した.

図一5,6はそれぞれ含水比を $22 \% に$ 調整した箱宮土， $28 \%$ に調整した二俣土に所定の安定材を $4 \%$ 添加したシ リーズ $\mathrm{A}, \mathrm{B}, \mathrm{C}$ 各供試体で測定した一軸圧縮強さ $q_{u}$ と 体積変化率 $\xi$ とをまとめたものである．これらの図で明 らかなように，安定材の添加率が同じでも強度の発現は 発生材を多く混入した供試体ほど大きくなり，これは上 述した $C B R$ 試験から得られた結果に一致している.ま た， $q_{u}$ の推移をみると， $q_{u}$ は空気中養生から水浸養生 に移行した時点で一旦低下寸るものの, その後漸次増加 していくことが認められる. このように, 水浸養生中に 強度の発現を呈することも $C B R$ 試験で示された傾向に 似通っている. しかし，図一5を試料土の設定含水比な らびに配合条件が同じである前出図一 4 に比較すると， 水浸養生終了時と空気中養生終了時との強度差は $C B R$ の差ほど顕著ではないことがわかる，一方， $\xi$ の 推移をみると，供試体は空気中養生の初期の段階で $1 \%$ 未満の体積膨張を生じるものの，それ以降は水中にあっ ても膨張も収縮も生じないこと，さらに， $q_{u}$ の大きな 供試体ほど $\xi$ もききなることがわかる.

なお，同一の配合条件でも〔箱宮土十消石灰〕をべー スとする供試体の $q_{u}$ は[箱宮土十セメント〕をべース とする供試体の1.5 2.5倍の値， $\xi$ は $1 / 2$ 程度の值とな
二俣土 $\mathrm{w}=28 \%$, セメント系固化材 $4 \%$ 添加 OシリーズA



図一6 養生期間中における一軸圧縮強さおよび 体積変化率の推移（二俣士の例）

り，箱宮土にかぎれば消石灰の添加は固化反応の促進効 果と膨張の抑制効果とを同時にもたらしたことになる. 参考までに，著者らの一部は，以前に石炭灰に消石灰を 混合して締固めた供試体の水浸強度の発現過程や体積膨 張過程を調べたことがあるが，その研究においても今回 のような消石灰の効用が認められた ${ }^{16)}$.

ここまでの室内試験から得られた結果を整理したとこ ろ, 水浸養生終了時における $C B R$ と $q_{u}$ との間には直線 関係が認められ，算出した回帰直線式（デー夕数 $\mathrm{N}=18 ）$ によれば〔箱宮土十セメント〕をべースとする供試体の $C B R$ は $q_{u}$ の約 6 倍, 〔二俣土十固化材〕の供試体の $C B R$ は $q_{u}$ の約 9 倍に相当していた.

以上のように, 粒径 $13 \sim 10 \mathrm{~mm}$ の発生材を混入した安定 処理土（シリーズ $\mathrm{B} ， \mathrm{C}$ ) の $C B R$ および一軸圧縮強さ は通常の安定処理土（シリーズA）を下回ることはなく， また, 吸水膨張量や体積変化率からみた変形性状も実用 上とくに問題になるようなものではないと考えられる.

このことから，本研究では引き続き屋外に模擬路床を 構筑して, 事前の室内試験では取り扱わなかった粒径 40 〜 0 mmの発生材をも使用して施工性や構築後の地盤反力 倸数 $K_{30}$ の経時変化を調べることにした. 模擬路床に用 いる試料土としては箱宮土，二俣土のどちらでも差し支 えなかったが，工事現場で採取した二俣士の残量が懸念 されたために入手の容易な箱宮土を採用することにした.

\section{4. 模擬路床の構築試験および室内確認試験の結 果}

\section{（1）施工概要および計測結果}

屋外試験は，石川県小松市近郊のアスファルトプラン 


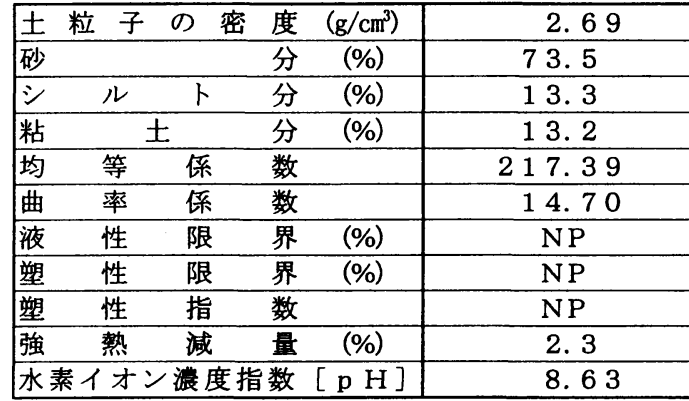

卜敷地内の一角で実施した. 表一 5は試験箇所の表層土 の物理的性質を，また，表一6は「模擬路床の構築試験」 および屋外での調查を終えてから改めて実施した「室内 試験」における材料の組み合わせを示す．ここで，第 2 章および第 3 章に示した $C B R$ 試験の結果にもとづけば 箱宮土に対するセメント添加率は $2 \%$ としても不足では ないが, 後述する箱宮土の構築当日の自然含水比, 安定 処理厚や施工時期などを考慮に入れて添加率を割り増し し，現場配合では $4 \%$ とすることにした.

模擬路床の構築手順としては, 初めにバックホウで幅 $2 \mathrm{~m}$, 長さ $12 \mathrm{~m}$ の区画 (4区画) を $30 \mathrm{~cm}$ の梁さまで掘削, ブルドーザで不陸整正を行った. 続いて, 区画の周囲に 高さ約 $30 \mathrm{~cm}$ の提を筑き, そこへ土取り場から搬入した 箱宮土を敷きならした. その際, 箱宮土が乾燥している 場合には水を散布して含水比調整を行うことも予定して いたが, 前日から当日未明にかけて降雨があり, 含水比 は搬入した時点で 4 〜 27\%に達していたので, とくに水 分を調整することなくそのまま敷きならした. 在来路床 とみなす土層の仕上がり厚さは $50 \mathrm{~cm}$, 乾燥密度は $1.5 \sim$ $1.6 \mathrm{~g} / \mathrm{cm}^{3}$ (最大乾燥密度の約 $90 \%$ 相当値)を目標に $3 \mathrm{t}$ のタイヤローラで締固めた. 走行 1 回ごとに $R I$ 式水分 密度計により乾燥密度を求めたが，2往復した段階で概 ね所定の状態に仕上がった。

次に，土層上にセメントを散布，発生材を敷きならし た後にスタビライザで 1 回の混合（混合速度 $4 \mathrm{~m} / \mathrm{min}$ ) を行った. 混合後の締固め作業には, $3 \mathrm{t}$ と15 t のタイ ヤローラを併用した. 計 4 往復の転圧で目標とした乾燥 密度1. $6 \sim 1.7 \mathrm{~g} / \mathrm{cm}^{3}$ に達し, 模擬路床の最終的な仕上が り厚さは工区 $1 \sim 4$ でそれぞれ $50 \mathrm{~cm}, 52 \mathrm{~cm}, 53 \mathrm{~cm}, 55 \mathrm{~cm}$ (各工区とも6箇所の平均値) となった.

このように，室内試験では配合条件のいかんを問わず 作製した供試体はすべて同じ高さとなるが，実地では発 生材の量が増えるほど, そして, 最大粒径が大きいほど 施工基盤としての水集面は扛上していくことになり，し たがって，本研究で設定した混入率 $20 \%$ というのは実用

\begin{tabular}{|c|c|c|}
\hline $\begin{array}{l}\text { 構 築 } \\
\text { 試験 } \\
\end{array}$ & 室内試験 & $\begin{array}{l}\text { 普通ポルトランドセメント㳢加率 } \\
\text { および 発生材混入率 } \\
\end{array}$ \\
\hline エ区 1 & シリーズ1 & 箱宮土十セメント 4\% \\
\hline 工区 2 & シリーズ2 & 箱宮土十セメント $4 \%+$ 発生材 $[13 \sim 10 \mathrm{~mm}] 10 \%$ \\
\hline 工区 3 & シリーズ3 & 箱宮土十セメント $4 \%$ +発生材 $[13 \sim 10 \mathrm{~mm}] 20 \%$ \\
\hline 工区 4 & シリーズ 4 & 箱宮土十セメント $4 \%+$ 発生材 $[40 ０ \mathrm{~mm}] 20 \%$ \\
\hline
\end{tabular}

上の上限に近い量と考えられる.

各工区には, 熱電対 (クロメル・アルメル) を2本ず つ埋設して路床温度を計測した. 埋設位置は長さ方向 $3 \mathrm{~m}$ と $9 \mathrm{~m}$, 深さは約 $40 \mathrm{~cm}$ とした. また, 定期的に平板 載荷試験を実施して, 固化の進行状況を確認した.

図一7は，模擬路床を構筑した1996年10月から撤去し た1997年4月までの路床温度の計測記録（破線）を示す. 実線は事後の室内試験で設定した供試体の養生温度であ り,これについては次節で述べる. 路床面の覆いは市販 のビニールシートのみとしたこともあって, 路床温度は 外気温度の変動に概ね追随していた. それでも, 日平均 気温が下降した1996年12月下旬から翌年 2 月中旬にかけ $\tau$, 路床温度は日平均気温より $2^{\circ} \mathrm{C}$ 前後高く推移した.

現道, すなわち, 路床の上に舗装を有する道路におけ る路床温度の季節変動について, 新潟市内の車道用透水

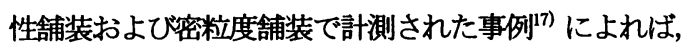
路面下 $80 \mathrm{~cm}$ 深さにおける路床の月平均温度は舖装構造 の区別なく 7 月でおよそ $32^{\circ} \mathrm{C}, 10$ 月で $22^{\circ} \mathrm{C}, 12$ 月で $9^{\circ} \mathrm{C}$,

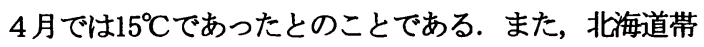
広市近傍の農道での計測記録をもとに路床面温度（路面


温度が最高, 最低となった約 1 ケ月後に路床面温度が最 高, 最低となり, 変動曲線上では 8 月に $23^{\circ} \mathrm{C}, 10$ 月に $17^{\circ} \mathrm{C}$, 12 月に $4^{\circ} \mathrm{C}, 2$ 月に $-2{ }^{\circ} \mathrm{C}, 4$ 月には $4^{\circ} \mathrm{C}$ を辿っていた とのことである.

これら $2 つ の$ 報告のうち, 文献17）は今回の屋外試験 籄所と気象噮境が似ている地域での計測事例であり, 上 記の10月〜 4月の路床温度を図一7に照合すると，本研 究で取り扱った舗装をともなわない模擬路床でも，温度 条件に関するかぎり結果的には実際から極端に逸脱して いなかったと考察することができる.

表一 7は表層土の掘削・整正時 (原地盤)，模擬路床 を構築した当日および構築後 $7 ， 30 ， 90 ， 180$ 日目に各 工区で測定した地盤反力係数 $K_{30}$ をまとめたものである. 0日から180日の平板載荷訌験において載荷点の隔たり はいずれも $2 \mathrm{~m}$ とし, 試験自体は文献19）に解説されて いる手順にしたがって実施した. この表より, 各工区と も改良路床土の支持力は当初の 1 週間で急增しているこ 


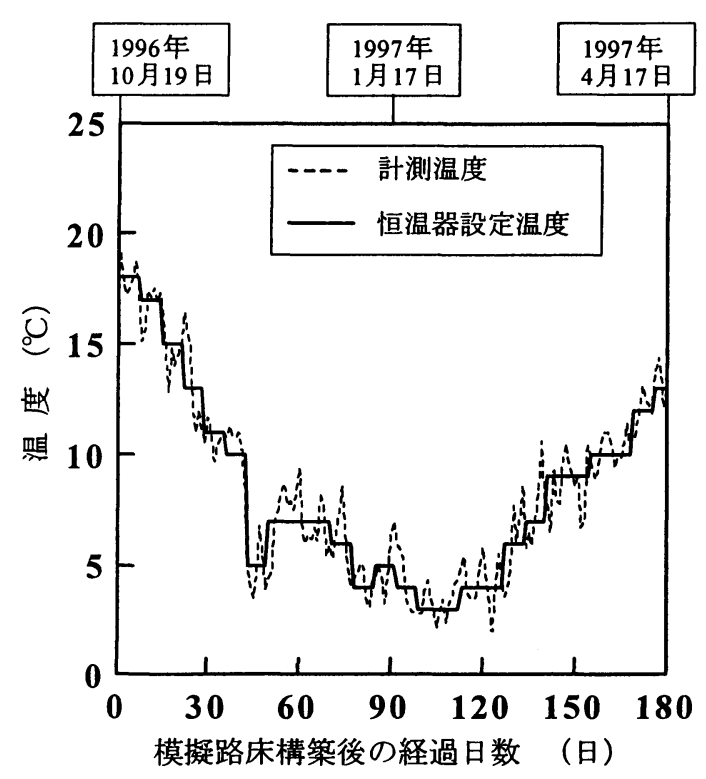

図一7 模擬路床の内部温度と設定した養生温度

と，さらに，7 日以降 180 日までの $K_{30}$ の值は通常のセ メント安定処理土（工区1）, 単粒度の発生材を $10 \%$ 混 入した処理土（工区 2 ）, 同じ発生材を $20 \%$ 混入した処 理土（工区 3），粒径 40〜 0 mmの発生材を $20 \%$ 混入した 処理土（工区4）の順に大きくなっていることがわかる.

したがって, 表一フに示した $K_{30}$ の経時変化のみに着 目すれば，グリズリフィーダ通過材をそのまま使用する 方がより大きな改良効果をもたらすことになる. しかし， $K_{30}$ の值には原地盤の支持力の差や路床の厚さの違いに よる影響も多分に含まれているとみなされるので，今回 の測定結果だけでグリズリフィーダ通過材（粒径40〜 $0 \mathrm{~mm}$ ）の有用性を的確に評価するのは難しく，この点に ついては次章でさらに検討を加えることとする.

\section{（2）事後試験および結果}

屋外での調査が終了した時点で, 模擬路床の固化の進 行におよぼした路床温度の影響を明らかにする目的で， 現場密度と含水比とを目標に静的に楴固めて作製した供 試体（直径約 $100 \mathrm{~mm}$, 高さ約 $127 \mathrm{~mm}$ ) に対する一軸圧縮試 験に着手した．具体的には，実地計測温度を模倣した温 度, すなわち, 前出図ー7に示した実線のとおり温度を 調節した恒温器内にビニール袋で敵封した供試体を静置 し, 所定の養生日数に達したときの一軸圧縮強さ $q_{u}$ を測 定した. なお, 恒温器の温度調節は 7 日ごととし, 供試 体の材路は最長180日とした。一軸圧縮試験は，1\%/min のひずみ速度で行った.

さらに，屋外試験では確かめることのできなかった改
表一7 各工区における地盤反力係数 $K_{30}$ の実測值

\begin{tabular}{|c|c|c|c|c|c|c|}
\hline \multirow[b]{2}{*}{$\begin{array}{l}\text { I } \\
\text { 区 }\end{array}$} & \multirow[b]{2}{*}{ 原地 } & \multicolumn{2}{|c|}{ 施 I 後 } & \multirow{2}{*}{$\begin{array}{c}\text { 経 過 } \\
30 \text { 日 } \\
\text { [1 ケ月 }]\end{array}$} & \multicolumn{2}{|l|}{ 日 数 } \\
\hline & & $\begin{array}{c}0 \text { 日 } \\
\text { [構筑当㫙 }\end{array}$ & 7 日 & & $\begin{array}{c}90 \text { 日 } \\
\text { [3ヶ月] }\end{array}$ & $\begin{array}{l}180 \text { 日 } \\
\text { [6ヶ月] }\end{array}$ \\
\hline 1 & 13.9 & 1.8 & 30.9 & 36.7 & 39.9 & 37.1 \\
\hline 2 & 17.4 & 2.5 & 36.5 & 47.9 & 49.3 & 53.0 \\
\hline 3 & 17.4 & 2.1 & 46.8 & 54.6 & 61.8 & 59.4 \\
\hline 4 & 28.0 & 3.2 & 80.1 & 89.8 & 94.3 & 91.2 \\
\hline
\end{tabular}

良路床土の水に対する抵抗性の良否を判定する手蛙かり として,「安定処理土の $C B R$ 試験方法」 ${ }^{15)}$ に準拠して 求める $C B R$ (セメント安定処理の場合 : 空気中養生 3 日 十水浸養生 4 日）に加えて，空気中養生後の水浸期間を 最長90日まで延長したときの $C B R$ も求めた. 以後，工 区 $1 \sim 4$ の配合条件に対応する一軸圧縮試験用およひ $C B R$ 試験用の供試体を，シリーズ $1 \sim 4$ と表記するこ とにする（前出表一6参照）。

図一8（a）は，シリーズ 1〜4の供試体における一軸 圧縮強さ $q_{u}$ の推移をまとめたものである. この図には， 恒温器の設定温度も併記してある. どのシリーズにおい ても $q_{u}$ の増加は養生開始後 30 日までと 150 日以降に認め られ，その間 (60～120日) の $q_{u}$ はほぼ一定となってい る. このような $q_{u}$ の経時変化を恒温器の設定温度に照合 してみると，強度を発現していなかった期間というのは 供試体を $7^{\circ} \mathrm{C}$ 以下で養生していた期間に概ね該当するこ とがわかる. また，養生期間中の $q_{u}$ は終始シリーズ 1 , $2 ， 3 ， 4$ の順に大きくなっており，この序列自体は先 の模擬路床における平板載荷試験の結果（表一7）に一 致している. ただし, シリーズ 4 と 3 との強度差は発生 材の粒度組成の違いによるものというほど顕著ではない．

盖生終了時における体積変化率 $\xi$ の最大はシリーズ 3 および 4 の約 $2 \%$, 最小はシリーズ 1 の約 $1.5 \%$ であ り，わずかな差ながらも発生材の混入率に関連していた.

図一8（b）は，改良路床土の強度特性におよぼす養生 温度の影響をより明確なものとするために, シリーズ 1 および 4 の供試体をそれぞれ $5^{\circ} \mathrm{C}, 20^{\circ} \mathrm{C}$ に設定した恒温 器内に静置したときの一軸圧縮強さ $q_{u}$ の測定結果を示す シリーズ 1,4 ともに $5{ }^{\circ} \mathrm{C}$ 温度条件下における強度の 発現は小さく，養生30日以降に $q_{u}$ の増加はほとんど認め られない. 一方, $20^{\circ} \mathrm{C}$ の温度条件下では $q_{u}$ は着実に増 加し, 半年程度の養生では未だ最終強度に達していない. 180 日目の $q_{u}$ を比較したところ, シリーズの区別なく $20^{\circ} \mathrm{C}$ で養生した供試体の $q_{u}$ は $5{ }^{\circ} \mathrm{C}$ で養生した供試体の約 2 倍 の値となっていた. さらに, 図一8（a）に示したシリー ズ 1 (記号○) およびシリーズ $4(\diamond)$ の $q_{u}$ は, 図一 8 (b)におけるそれぞれの $5{ }^{\circ} \mathrm{C}, 20^{\circ} \mathrm{C}$ 強度曲線のほぼ 中間に位置することが確かめられた。

養生温度を「調節」または「一定」とした上記の一軸 




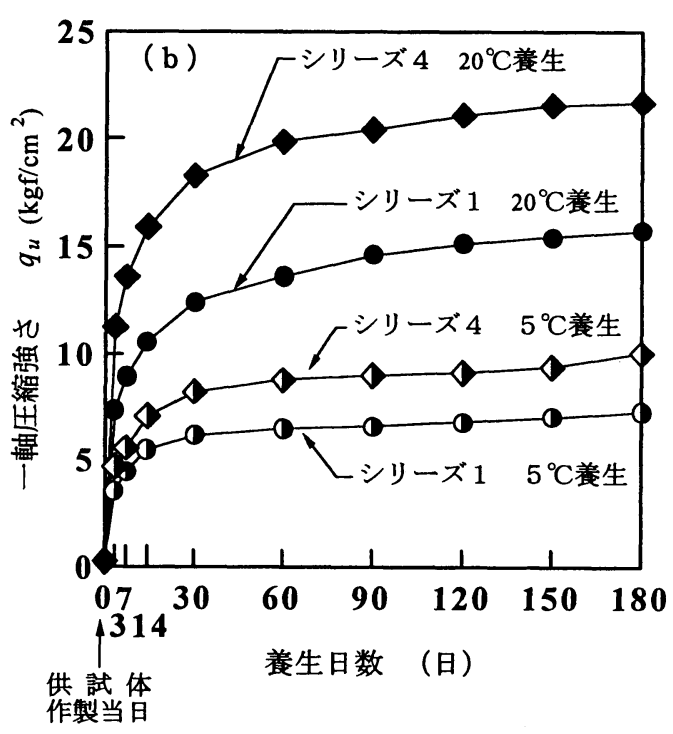

図一－軸王縮強さの経時変化（温度估存性の確認）

圧縮試験から，模擬路床の固化の進行には路床温度が深 く関与していた可能性の高いことが示され，今回は低温 期を控えて模擬路床を構筑したが，施工時期が 4 ケ月程 度前倒しであったならば, すなわち, 高温期に先駆けて 構築していたならば, 地盤反力係数 $K_{30}$ の増加割合は一 層大きくなっていたものと推測される.

安定処理土の温度依存性について, まさ土に高炉セメ ントB種あるいは消石灰を $4 \%$ 添加して作製した供試体 を, 8 種類の温度条件 (最低: $-9^{\circ} \mathrm{C}$, 最高 $33^{\circ} \mathrm{C}$ ) のも とで養生したときの一軸珐縮強さ $q_{u}$ を測定した結果 ${ }^{20)} に$ よれば, $q_{u}$ は高い温度で養生するほど大きくなり, 例え ば, $21^{\circ} \mathrm{C}$ 標準温度で120日間養生したセメント安定処 理土の $q_{u}(3.1 \mathrm{MPa})$ は $3^{\circ} \mathrm{C}$ およそ2 倍に相当すると のことである. また，養生中に $-9^{\circ} \mathrm{C} て ゙$ 供試体を一旦凍 結させても，その後標淮温度で養生すると $q_{u}$ は経時的に 増加するとのことである. さらに，この論文には，予め 空気中で 6 日間養生した供試体を水浸しても, 長期にわ たり強度低下を生じないことが併せて述べられている.

したがって, セメントの種類，材料構成や養生方法は

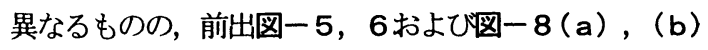
に示した強度発現過程のおおよその根拠を文献20）の研 究成果から窥い知ることができると考えられる.

次に, 図一 9 はシリーズ 1 および 4 の $C B R$ 試験用供 試体を作製した当日, 空気中養生（3日間）終了時およ び水浸養生 $4 ， 14 ， 30 ， 60,90$ 日目に求めた $C B R$ をま とめたものである. 空気中養生の段階でシリーズ 4 の $C B R$ はシリーズ 1 の約 $30 \%$ 増となっており，その差は 水浸養生に移行した後もほとんど変わらないことがわか る. 水浸 $C B R$ の推移をみると, シリーズ 1,4 ともに
$C B R$ は極端に低下することなく, むしろ徐々に増加す る傾向にあることが認められる. 同様の傾向は, 単粒度 の発生材を混入したシリーズ 2 および 3 の供試体におい ても示された. なお，90日間の水浸養生中に生じた吸水 膨張量は, 配合条件にかかわらずいずれも $0.1 \mathrm{~mm}$ 未満で あった.

この章に述べた模擬路床の構築詿験において，発生材 はその粒度組成を調整しなくても路上混合方式による路 床改良工事に適用可能であり，セメントの混合むらや締 固め度（路床構築における品質管理の限界値 $\geqq$ 最大乾燥 密度の85〜90\%） ${ }^{3)}$ の不足を生じる㲘念のないこと，た だし，多量に使用するときには在来路床表層の一部撒去 を行わないかぎり出来形管理の限界（基淮高 : $\pm 5 \mathrm{~cm}$ 以 内） ${ }^{3)}$ に抵触する場合もあることが確認された.

室内での事後試験からは, 発生材混入の有無ならびに 最大粒径の違いを問わず, 改良路床土の固化反応の遅速 は路床温度に依存する部分が多く, $7{ }^{\circ} \mathrm{C}$ 前後を境として 強度の発現過程に差異を生じること，また，粒度組成に 比べて混入量の方が強度および変形特性に直接的な関係 をもつこと, さらに, 発生材を混入した改良路床土の水 に対する抵抗性を通常のセメント安定処理土と比較して もとくに遜色のないことが明らかにされた.

\section{5. 路床構築後の支持力増分に関する数値計算例}

先の第 4 章 (1) で, 模擬路床構築後の地盤反力係数 $K_{30}$ には工区による相違, すなわち, 発生材混入の有無, 加えた発生材の量や粒度組成の違いによる大小関係が認 められたことを述べた。一般に，平板載荷の影響がおよ 


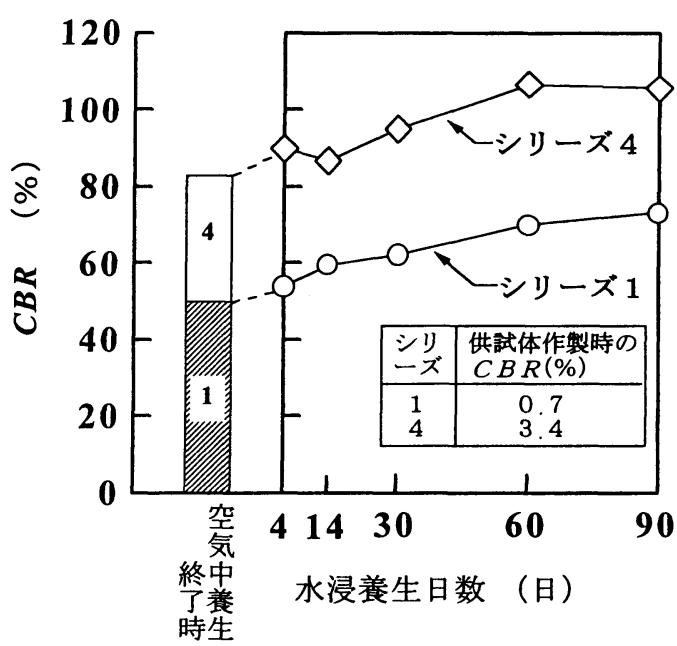

図-9 水浸 $C B R$ 経時変化 (而水性の確認)

ぶ範囲は深さ方向に載荷板直径の1.5〜2倍とされてお $\eta^{21)}$ ，これを今回の試験状況に当て嵌めると，各工区に おける改良路床土層（厚さ $50 ５ 5 \mathrm{~cm}$ ） と原地盤の一部と を含めた領域の支持力特性を評価していたとも考えられ る. ところが，原地盤の $K_{30}$ には工区により倍近くの差 があり, 加えて, 構築 7 日以降に路床面で測定した $K_{30} に$ は，上述した路床温度がかかわっていた可能性が高い。 したがって, 原地盤と路床温度双方の影響を考慮に入れ た手法をもって, 発生材の混入が路床支持力の増加に与 えた効果について考察する必要がある.

その手掛かりとして, 著者らは鉄道の強化路盤の設計 などに多用されている「多層系弾性モデルによる路盤効 果の推定法」 ${ }^{22)}$ に着目し, 設計 $C B R$ が $2,3,4,6 \%$ の 在来路床を前出表一 6 の配合条件で改良した後に期待さ れる $C B R$ を計算により求めてみることにした.

作成した演算プログラムの概略を示すと, まず, 計算 過程に原地盤の堅さの影響を組み込むために, 次式 ${ }^{23)}$ 引用して $C B R=2 \sim 6 \%$ に対応する $K_{30}$ を設定した.

$$
K_{30}=0.55 \cdot C B R+2.2
$$

演算の第 1 段階では $K_{30}$ とともに在来路床のポアソン 比 $\nu_{\mathrm{s}}$, 層厚 $h_{\mathrm{s}}$ をプログラムに入力して路床の変形係 数 $E_{\mathrm{s}}$ を算出するが，その際， $\nu_{\mathrm{s}}$ について文献24） を参照して 0.4 と仮定し, また, $h_{\mathrm{s}}=\infty$ と置いた. 出力 データによると, 上式により $C B R$ から換算した 4 種類 の $K_{30}$ に相応する $E_{\mathrm{s}}$ の值は, $65.3 \sim 108.9 \mathrm{kgf} / \mathrm{cm}^{2}(6.4$ $\sim 10.7 \mathrm{MPa}$ ) となった.

演算の第 2 段階は路床温度の影響を取り入れた改良後 の地䑪反力係数 $K_{30}{ }^{*}$ の算出であり, ここでは上記 $\nu_{\mathrm{s}}$, $h_{\mathrm{s}}, E_{\mathrm{s}}$ の諸值を有する在来路床の上に改良層を載せ た 2 層系モデルとして計算を進めた. 解析にあたって,
安定処理厚 $h_{\mathrm{n}}$ には模擬路床の仕上がり厚さである50〜 $55 \mathrm{~cm}$ 代入し, その層のポアソン比 $\nu_{\mathrm{n}}$ は $\nu_{\mathrm{s}}$ と同じく 0.4 と置いた. そして, もう1つの入力データである改 良路床土層の変形倸数 $E_{\mathrm{n}}$ には, 温度を「調節」または 「一定」として養生した供試体の一軸圧縮試験（前出図 -8) から得られた $E_{50}$ を代用した. $E_{50}$ の範囲は, 16.8 〜3578. $0 \mathrm{kgf} / \mathrm{cm}^{2} \quad(1.6 \sim 350.6 \mathrm{MPa})$ である.

最後に，第 2 段階で求めた $K_{30}{ }^{*}$ を式(1)の $K_{30}$ に 置き換えて改良後の $C B R^{*}$ を逆算した.

計算結果の 1 例を図一10に示寸（a)はセメントのみ を添加した処理土（シリーズ 1)，（b）は粒径40〜 0 m の発生材を $20 \%$ 混入したセメント安定処理土 (シリーズ 4) の出力データのうち, 路床を構築してから 7〜60日 分をまとめたものである.

この図において, 改良後の $C B R^{*}$ をシリーズ 4 と 1 と の比で表してみると温度条件, 改良前の $C B R$, 経過日数 にかかわらず概ね 1.4 となり, 計算上でも発生材を混入 する方が支持力の增分は大きくなることがわかる. なお， 粒径 13 〜 $10 \mathrm{~mm}$ の発生材を $10 \%$ 混入したシリーズ 2 と 1 と の比は約 1.2 , 同じ発生材を $20 \%$ 混入したシリーズ 3 と 1 との比は約1.4であり， $C B R^{*}$ は発生材の粒度組成で はなく混入量に関連して増加することが確かめられた。 また， $C B R^{*}$ を温度条件に注目して比べてみると，いず



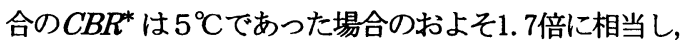
温度が徐々に下降していった場合の $C B R^{*}$ はこれらのほ ぼ中間の値となっている.このことから, 構筑後の路床 支持力の早期増加を期待する上には, 施工時期に応じて 発生材や安定材の量を適宜加减する必要もあるものと考 察される.

路床設計の実務においては改良層の $C B R$ の上限は $20 \%$ とするので, 例えば図一10(b) のような大きな $C B R$ を 目標に構築を図ることはない. それでも，ここに示した 2 層系モデルを用いた計算手法によって発生材を混入し た安定処理土の支持力増分を調べることは, 当該処理土 を一種の路床構筑材料とみなしたときの材料特性の把握 や評価に有用と考えられる.

\section{6. まとめ}

供用後のライフサイクルを延長し, 維持・修繥に要す る費用を低减するためには，大きな支持力を有する路床 の上に荷重分散機能を高めた材料, 断面構造から成る舗 装を設ける必要がある. その一方で, 建設リサイクル推 進計画 '97の根幹をなす「ゼロ・エミッション」の達成 に向けて, 道路工事のみならず土木事業全般にわたり廃 㶳物の発生抑止ならびに建設副産物の積極的な活用が求 められている. 


\begin{tabular}{|cccc|}
\hline \multicolumn{4}{|c|}{ 改良後の経過日数 } \\
\hline 0 & 7 日 & $\triangle$ & 14 日 \\
$\square$ & 30 日 & $\diamond$ & 6 日 \\
\hline
\end{tabular}

[温度条件 : 調節 $\left.{ }^{\dagger}\right]$

\begin{tabular}{|c|c|c|c|c|}
\hline 経過日数 & 7 & 14 & 30 & 60 \\
\hline 温度 $\left({ }^{\circ} \mathrm{C}\right)$ & 18 & 17 & 1 & 7 \\
\hline
\end{tabular}

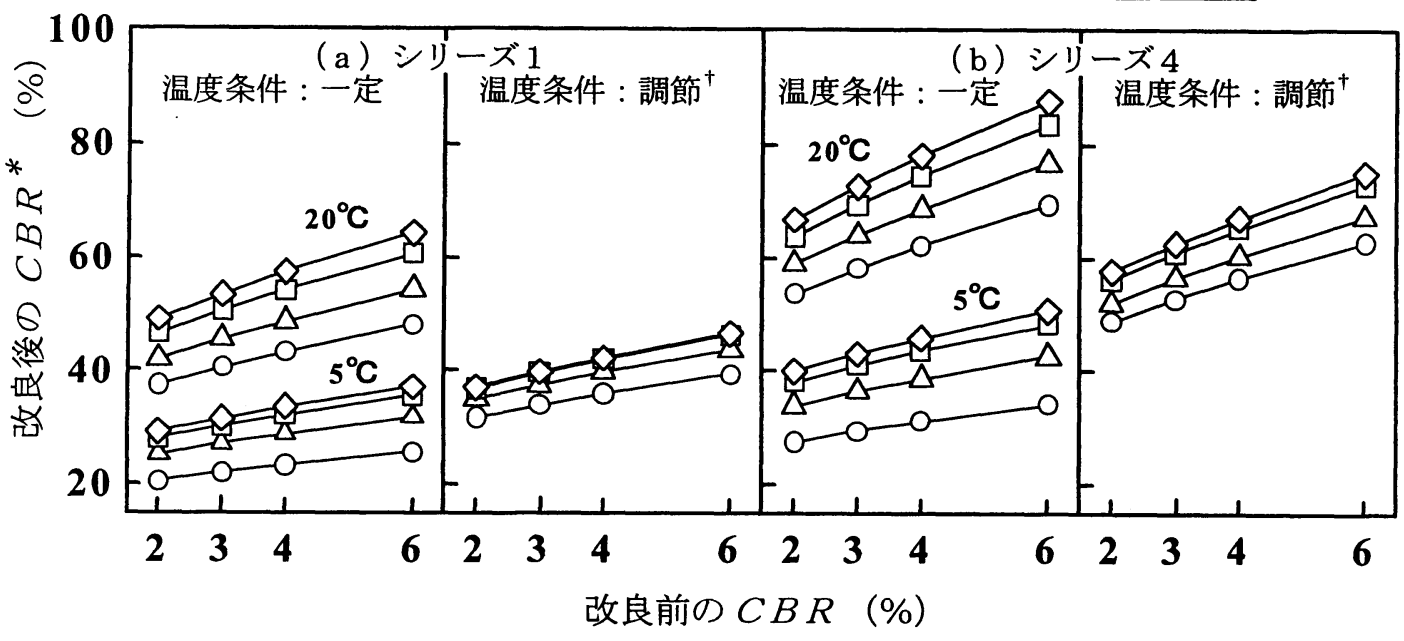

図-10 改良前後の路床支持力の比較（計算值）

このようなアスファルト舗装の強化，長寿命化にかか わる路床構築技術の必要性と環境保全，天然資源の節約 にかかわる昨今の趨勢とを踏まえて，著者らは再生資源 の 1 つである粒径40〜 0 mmのグリズリフィーダ通過材 （発生材）を用いた路床構筑の可否について検討するこ とにした。研究では室内 $C B R$ 試験，一軸圧縮試験によ り発生材を混入した安定処理土の工学的性質を調べると ともに，屋外で小規模な構築試験を実施して施工性や路 床支持力の経時変化を調べた. さらに，簡便な数值計算 を行って発生材混入の有無, 温度条件と $C B R$ の增分と の関係について考察を加えた.

本研究で得られた主要な結果を要約すると, 次のよう になる.

（1）供試体を空気中で養生した場合，発生材を混入 した安定処理土の $C B R$ および一軸圧縮強さ $q_{u}$ は安定材 のみを添加した処理土の $C B R, q_{u}$ を確実に上回り，そ の傾向は発生材を多く混入するほど顕著となる. また, 水中静置の状態でも $C B R, q_{u}$ が極端に低下する兆候は 認められず，むしろ時間の経過とともに漸増する。

（2）発生材の粒度組成にかかわらず，最長90日の水 浸養生中に生じた供試体の吸水膨張量, 最長180日の空 気中養生において生じた体積変化率 (膨張側) はともに 微量であり, 構築後に地下水や外気温度の影響を受けて 路床が変状を呈する恐れは少ない。

（3） 発生材の混入量が在来路床土の 2 割程度までで あるならば，通常の路上混合方式による施工に支障はな
く, 管理の限界に適った路床を構築できる可能性が高い. ただし，発生材の大量消費を試みる場合は仕上がり面の 扛上に注意を払う必要がある.

（4）安定処理土の支持力増加，強度発現の過程には 路床温度の関与する部分が多く, 平板載荷試験および事 後試験の結果をもとに推測すると, 路床温度がおよそ $7^{\circ} \mathrm{C}$ まで下降した時点から固化の進行に遅滞を生じる.

（5）上記(1)および（4)に関連して，試算した構築 後の $C B R$ を発生材の混入, 無混入で比較すると前者は 後者の $2 \sim 4$ 割増に相当し, また, 構築後 1 ヶ月間の路 床温度が $20^{\circ} \mathrm{C}$ であったとするときの $C B R$ は $5{ }^{\circ} \mathrm{C}$ のき の約1.7倍に相当する. したがって, 構筑時期を見計ら うことも目標設計 $C B R$ を定める上には肝要となる.

以上，本研究で実施した一連の試験から，グリズリフ イーダ通過材を混ぜ合わせた安定処理土の材料特性につ いてはおおよそを明らかにすることができたが，その路 床の上に舗装を設けた場合の効果，とりわけ交通開放後 の供用性能に関しては今後の検証課題として残された.

この点について, 現在, アスファルトプラント敷地内 のダンプトラック通行路および公道 (設計交通量 L, A 交通）において試験施工を行う方向で立案, 淮備を進め ており, 新たな知見が得られしだい稿を改めて報告する こととしたい.

謝辞 : 本研究は著者のひとり (筆頭者) が金沢工業大学 に在勤中から継続して行ってきたものであり, 終始適切 
なご助言を賜った金沢工業大学工学部土木工学科太田 実教授をはじめ，試験や結果の整理にご協力いただいた 当時の大学院修士課程学生保本敏伸氏 (現,ニチレキ(株) 勤務），富樫重臣氏（現，山形県庁勤務），山下哲弘氏

(現，大成ロテック(株) 勤務) ならびに当時の学部卒業 研究生諸氏に深甚なる謝意を表する. また，貴重な資料 の提供および助言を頂戴した建設省, 石川県, 日本道路 公団の関係各位に束心より御礼申しあげる.

\section{参考文献}

1）池田拓哉：舗装技術の現状と課題，土木技術，第54巻，第 2 号, pp. 28-34, 1999. 2.

2）稻垣竜興 : 長寿命舗装（現状と問題点），土木技術，第54 巻, 第 2 号, pp. 81-87, 1999. 2.

3）(社）日本道路協会: アスファルト舗装要網，1992. 12.

4）(社)廃裹物学会: 廃棄物ハンドブック, pp. 1147-1178, 1997. 11.

5）山田幹雄, 佐野博炤, 黒島一郎, 太田 実: 石炭火力発電 所産副産物の道路路盤材としての有用性に関する研究，土 木学会論文集，第510号/VI-26, pp. 125-135, 1995.3.

6）山田幹雄, 佐野博昭, 黒岛一郎, 太田 実: フライアッシ ユおよひ排煙脱硫スラッジの軽交通道路用路盤材としての 利用に関する研究，土木学会論文集，第546号/VI-32, pp. 199 $-210,1996.9$.

7）(社) 日本道路協会 : アスファルト混合所便筧（平成8年版）， 1996. 10.

8）建設副産物リサイクル広報推進会議：総合的建設副産物対 策一現場での実効ある対策の推倠のために一（平成10年度 版) , 1998.8 .

9) 本多淳栄, 山田 優: 建設副産物・廃珒物のリサイクル, (財) 省エネルギーセンター, pp. 293-353，1994. 8.

10）（社）日本道路協会: プラント再生舖装捕指針，1992.12.

11）山下哲弘，山田幹雄，太田 実，松島保志 : 再生材を利用 した道路路床の構築法に関する基磷的研究，土木学会第51
回年次学術講演会講演概要集，第 3 部(B)，pp. 544- 545 , 1996. 9.

12）松島保志, 山田幹雄, 太田 実, 坂田親紀 : 再生材を混合 した粘性土の強度, 支持力特性, 土木学会第52回年次学術 講演会講演概要集，第3 部(B), pp. 602-603, 1997.9.

13）坂田親紀，山田幹雄，太田 実, 谷口克也, 松島保志: 再 生路盤材を混合した路床土の強度, 支持力特性に関する一 考察，士木学会第53回年次学術講演会講演概要集，第 3 部 (B), pp. 646-647, 1998. 10.

14）(社)土木学会 : 土質試験のてびき, 1992.2.

15）（社）日本道路協会 : 舖装試験法便覧，1988.11.

16）山田幹雄，佐野博昭，徳岡研三，伊能忠敏：在来線噴泥対 策としての石炭灰を用いた置換互層路盤の適用性に関する 実験的研究，土木学会論文集，第444号/VI-16, pp. 31-40, 1992. 3.

17）荒井 進, 大川秀雄, 田口 仁, 大竹和彦: 新舄市におけ る車道用透水性舖装の試み，舗装，第33巻，第 3 号, pp. 8 $-15,1998.3$.

18）美洤宏樹, 秀島好昭, 沢田則彦: 農業用道路の舖装体温度 観測と考察, 農業土木学会北海道支部研究発表会講演要旨 集, Vol. 39th, pp. 58-63, 1990.

19）（社）土質工学会 : 土質工学会基淮一地盤の平板載荷試験方 法・同解説，1983.1.

20）三䳋棓雄，星野克之，森本美樹 : 安定処理土の強度特性と 耐久性に及ぼ寸影響, 日本道路公団圾験研究所報告, Vol. 32, pp. 10-23, 1995. 11 .

21）（社）地盤工学会 : 地盤調查法，pp. 345-361，1995. 12.

22）（財）鉄道総合技術研究所 : 鉄道構造物等設計標淮 - 同解説 一土構造物一, 1992.11.

23）植下 協: 舗装の力学 (最終回), 舗装, 第 8 巻, 第 9 号, pp. 33-38, 1973. 9.

24）伊東孝之, 関口吉男, 板井幸市 : 鉄道路盤の支持力, 鉄道 技術研究所速報，No.A-87-91，1987.3.

(1999. 5. 31 受付)

\section{EXPERIMENTAL STUDY ON EFFECT OF IMPROVEMENT OF SUBGRADE SOIL BY USING RECLAIMED ASPHALT MIXTURE WITH STABILIZER}

\section{Mikio YAMADA, Yasushi MATSUSHIMA, Hiroaki SANO and Mitsushi OKUMURA}

In order to investigate the effect of reclaimed asphalt mixture content on the mechanical properties of stabilized soils, California bearing ratio (CBR) tests and unconfined compression tests were performed under various compositions. In addition, plate loading tests were carried out to observe the hardening condition of stabilized subgrade soils containing reclaimed asphalt mixture.

As a result, it was found that the unconfined compressive strength and CBR value increased with an increase in reclaimed asphalt mixture content and that the hardening rate of stabilized soil tended to change in accordance with a variation of subgrade temperature. Therefore, selecting the execution season seems to perform an important role in forecasting the effect of improvement. 